buffer $(p H .6 \cdot 8)$ and from which the excess suspension was afterwards decanted. It shows $(a)$ a few scattered starch grains at the site of the buffered penicillin solution inside the 'penicylinder'; (b) starch grains sedimented in the trough, where the 'penicylinder' had rested (out of focus because in a different plane from the surface of the agar); (c) a narrow ring deroid of starch around the trough ; and $(d)$ the circumjacent wide band of starch grains covering most of the width of the inhibition zone and extending up to the 'ring of enhanced growth' where a few scattered grains appear on the right.

Conversely, the 'ring of enhanced growth', where starch fails to flocculate, is the site of heaviest deposition of silver following flooding of the plates with an aqueous solution of silver nitrate $e^{5,6}$, or of the red triphenyl formazan following treatment with solutions of triphenyl tetrazolium chloride such as have been used as indicators of seed viability 7,8 .

These observations may be taken as evidence of electro-negativity in the regions of enhanced growth and of positive charges in the zones of inhibition. No such responses are seen on unseeded plates exposed to penicillin. Thus the effects cannot be attributed to reactions of the reagents with penicillin diffusing from the cylinders.

The $p H$ effect postulated by Carr ${ }^{9}$ to account for the mechanism of the Feulgen reaction may be demonstrated by comparing plates stained with basic fuchsin at $p H$ values above $6 \cdot 2$ or below $4 \cdot 8$. The more acid solutions stain the colonies in the background intensely red, thus sharply outlining the unstained inhibition zones, from which the desoxyribose nucleic compounds have been dispersed. There is relatively poor definition of the zones on plates stained with the less acid solutions.

Grateful acknowledgment is made to the Cutter Laboratories, Berkeley, Califormia, for partial support of these experiments.

Jean Dufrenoy

Robertson Pratt

University of California College of Pharmacy,

The Medical Center,

San Francisco 22.

Feb. 11.

${ }^{2}$ Dorfman, V. A., Nature, 153, 169 (1944).

- Dorfman, V. A., and Kastorskaya, T. L., Mikrobiologia, 15, 69 (1946).

s Dorfman, V. A., Moldavskaya, E. A. M., Kastorskaya, T. L., and Zasypkina, P. S., Ann. Rev. Soviet Med., 3, 500 (1946).

- Loiseleur, J., Ann. Ferment., 4, 220 (1938). - Goyan, F. M., Dufrenoy, J., Strait, L. A., and Pratt, R., J. Amer.

- Pratt, R., and Dufrenoy, J., J. Bact., 55, 525 (1948).

- Cottrell, H. T., Nature, 159, 748 (1947).

'Porter, R. H., Durrell, M., and Romm, H. J., Pl. Physiol., 22, 149 (1947).

' Carr, J. G., Nature, 156, 143 (1945).

\section{Fœtal Hæmoglobin and Erythroblastosis}

THE hæmoglobin of the fœetus and the new-born child and the hæmoglobin of older children and adult people can be distinguished by their different resistance against $0 \cdot 1 \mathrm{~N}$ sodium hydroxide. At $p \mathrm{H} 12$ normal hæmoglobin is denatured very rapidly, whereas fœetal hæmoglobin is denatured only slowly. By using this difference in denaturating-rate, it is possible to calculate the amounts of fotal and later hæmoglobin present in small samples of blood ${ }^{1}$. A normal new-born child has only fœtal hæmoglobin. During the early months after birth, this hæmoglobin is gradually replaced by later hæmoglobin, at a rate of a little less than 1 per cent a day, so that after 120 days normally all fœtal hæmoglobin has disappeared. In prematurely born babies, later hæmoglobin appears only at the time that the child ought to have been born ${ }^{2}$.

In new-born children suffering from erythroblastosis fotalis caused by the $R h$ antagonism there is a marked difference in behaviour of the two hæmoglobins. The fœtal hæmoglobin is broken down very rapidly, so that in severe cases it has practically disappeared from the blood within about five days. In less severe cases the breakdown stops after about six days and a certain amount of the fœtal hæmoglobin remains. This remaining fœtal hæmoglobin disappears during succeeding months as it does in normal children. On the other hand, later hæmoglobin normally not found in the blood shortly after birth is already present in these patients at the moment of delivery. It is present in an amount up to $4 \mathrm{gm}$. per $100 \mathrm{c.c}$. of blood. This later hæmoglobin is not broken down, or only very slowly, during the serious hæmolysis, the fotal hæmoglobin being broken down rapidly. When the child survives, its amount rises slowly later on. The $R h$ antibodies which are the cause of the destruction of the red blood corpuscles and of the hæmoglobin have not the same action on the cells containing fœtal and later hæmoglobin respectively. Only those which contain fœtal hæmoglobin are hæmolysed.

The presence in the blood at the moment of birth of later hæmoglobin, which is not broken down in children suffering from erythroblastosis, must be the result of a reaction of the child before birth against the $R h$ antibodies of the mother.

\section{Zuider Ziekenhuis, Rotterdam.}

Feb. 2.

${ }^{1}$ Brinkman, R., and Jonxis, J. H. P., J. Physiol., 85, 117 (1935).

${ }^{2}$ Jonxis, J. H. P., Maandschr. v. Kindergeneeskunde, 6, 357 (1937).

\section{Action of Sulphuryl Chloride on Wool}

ONE of several general methods of making wool unshrinkable depends for its success on disulphidebond breakdown in the surface of the fibres. A solution of sulphuryl chloride in white spirit is sometimes used for this purpose ${ }^{1}$; but it has now been found that treatment which is effective with com. mercial fabric is relatively ineffective when the latter is freed from adsorbed soap and residual oil by extraction with alcohol and ether.

Samples of extracted and unextracted flannel $(2.5 \mathrm{gm}$.) were conditioned at 65 per cent relative humidity and $22 \cdot 2^{\circ} \mathrm{C}$. before being immersed in 100 c.c. of a 2.5 per cent (v./v.) solution of sulphuryl chloride in carbon tetrachloride for one hour at room temperature. After treatment, the samples were neutralized with sodium bicarbonate solution, washed in running water, and then milled by hand for fifteen minutes in 5 per cent soap solution. The resulting shrinkages are given in Table 1 , which includes data for an extracted sample to which 0.5 per cent by weight of oleic acid (I.V. 83.7) had been added before treatment with sulphuryl chloride.

\begin{tabular}{|c|c|c|}
\hline Fabric & Treatment & $\begin{array}{c}\text { Percentage shrinkage } \\
\text { in area }\end{array}$ \\
\hline $\begin{array}{l}\text { Extracted } \\
\text { Unextracted }\end{array}$ & $\begin{array}{c}\text { None } \\
\text { Sulphuryl chloride }\end{array}$ & $\begin{array}{r}42 \cdot 7 \\
3 \cdot 2\end{array}$ \\
\hline Extracted & ", & $25 \cdot 0$ \\
\hline Extracted + oleic acid & ," & $-7 \cdot 3$ \\
\hline
\end{tabular}

